\title{
Practicality of Islamic Religious Education Module Anti-Radicalism and Terrorism Nuance on Islamic Religious Educational Subject
}

\author{
$1^{\text {st }}$ Syahrizal \\ Biology Education Department \\ STKIP PGRI Sumatera Barat \\ Padang, Indonesia \\ syahrizalnasran@gmail.com
}

\author{
$2^{\text {nd }}$ Febrina Riska Putri \\ Indonesian language and \\ literature Education Department \\ STKIP PGRI Sumatera Barat \\ Padang, Indonesia \\ fbrnriska@yahoo.com
}

\author{
$3^{\text {rd }}$ Liza Yulia Sari \\ Biology Education Department \\ STKIP PGRI Sumatera Barat \\ Padang, Indonesia \\ lizayuliasari@yahoo.co.id
}

\begin{abstract}
The subject of Islamic Religious Education (IRE) is the compulsory subject in college. IRE subject in universities needs to be prepared, delivered, and practiced in a practical and efficient way to prevent the development of student thoughts and behaviors leading to the occurrence of acts of radicalism and terrorism. Prevention of the action of radicalism and terrorism among students can be done by providing IRE module that nuanced anti-radicalism and terrorism during the lecture. IRE module nuanced anti-radicalism and terrorism can be a bridge of student knowledge with the reality of life. The purpose of this research is to produce IRE module nuanced anti-radicalism and terrorism which practically in IRE subject. This research uses development research design with 4-D development model. This development model consists of 4 stages: define, design, development, and disseminate. In this study, it is limited to the module practicality stage. Practicality of the module is done by trial and filling questionnaires by 12 students who are taking IRE subject. IRE module nuances of anti-radicalism and terrorism is categorized as practical with practical value of $85.97 \%$. It can be concluded that the Islamic religious education module nuanced anti radicalism and terrorism has been used in learning in STKIP PGRI Sumatera Barat.
\end{abstract}

Keywords - practicality; module; anti radicalism; terorism

\section{INTRODUCTION}

. The subject of Islamic Religious Education (IRE) is the compulsory subject in college. The subject of IRE is the Basic General Subject (MKDU) in STKIP PGRI Sumatera Barat. IRE subject is given so that students understand the teachings of Islam, practicing the teachings of Islam in life, critical thinking, and responsible. Improving the quality of IRE is expected to solve the multidimensional crisis in our country, especially the moral-ethical aspect, build the character and civilization of the nation, so that learners become human beings who believe, have the noble character, and become citizens of democratic and responsible (Nurlaila, 2011). IRE has an important position in the national education system because it aims to form the nation's spiritual morals, character building, and personality of the nation (Kosim, 2015).

IRE subject in universities need to be prepared, delivered, and practiced in a practical and efficient way to prevent the development of student thoughts and behaviors leading to the occurrence of acts of radicalism and terrorism. Radicalism and terrorism are attempts to create fear, horror, and cruelty by a certain person or group (Big Indonesian Dictionary). Terrorism is the unlawful use of force to achieve political objectives. The target of terrorism is innocent and sinful civil society (Laqueur, 1977).

Prevention of the action of radicalism and terrorism among students can be done by providing IRE module that nuanced anti radicalism and terrorism during the lecture. A module is a selfcontained, formally structured learning experience with a coherent and explicit set of learning outcomes and assessment criteria (Rufiil, 2015). Some of the masses of the material and the mastery of the material need mastery of the material and Dick and Carey, 2001).

IRE module nuanced anti radicalisms and terrorism can be a bridge of student knowledge with the reality of life. The IRE module in the college contains material derived from the Qur'an and hadith which describes the humanistic and tolerant teachings of Islam. The IRE module can shape the character of the students to live tolerant in religious and cultural diversity according to the philosophy of Bhineka Tunggal Ika. The purpose of this research is to produce IRE module nuanced anti radicalism and terrorism which practically in IRE subject. The module used in the IRE subject has been in accordance with the achievements of learning but has not nuanced anti radicalism and terrorism and has not provided an understanding of the solution and the prevention of acts of radicalism and terrorism. The development of IRE module nuanced anti radicalism and terrorism has been developed in elementary 
school (Rokhmad, 2012). The development of PAI modules of anti radicalism and terrorism in universities has never been done.

\section{METHODS}

The type of research that will be conducted is research development (Research and Development / $\mathrm{R} \& \mathrm{D})$. The product to be developed is the IRE module nuanced anti radicalism and terrorism that are valid, practical and effective. This research uses development research design with the 4-D model (Trianto, 2010). This development model consists of 4 stages: define, design, development, and disseminate. In this study, it is limited to the practicality stage of module.

The practicality of the module is done by trial and filling questionnaires by 12 students who are taking IRE subject. Questionnaires IRE module nuanced anti radicalism and terrorism arranged in the form Likert scale with positive statements. The data of student responses were analyzed by the following steps.

a. Provide score for each item of answers, Strongly Agree (4), Agree (3), Disagree (2), and Strongly Disagree (1).

b. Sums up the total score of each validator for all indicators.

c. Giving practicality value by using the formula:

$$
\mathrm{P}=\frac{\sum f}{N} x 100 \%
$$

The results obtained are interpreted using the following criteria:

TABLE 1. THE ASSESSMENT TOOL

PRACTICE CATEGORIES

\begin{tabular}{|c|l|}
\hline Values (\%) & Category \\
\hline $80<\mathrm{P}=100$ & Very Practical \\
\hline $60<\mathrm{P}=80$ & Practical \\
\hline $40<\mathrm{P}=60$ & Practical enough \\
\hline $20<\mathrm{P}=40$ & Less Practical \\
\hline $\mathrm{P}=20$ & Not Practical \\
\hline
\end{tabular}

Source: Modified from Riduwan (2010).

\section{RESULTS AND DISCUSSION}

The questionnaires and questionnaires from the IRE module containing anti-radicalism and terrorism on 12 students of STKIP PGRI Sumatera Barat showed that the module that has been designed is categorized as practical (Table 2).

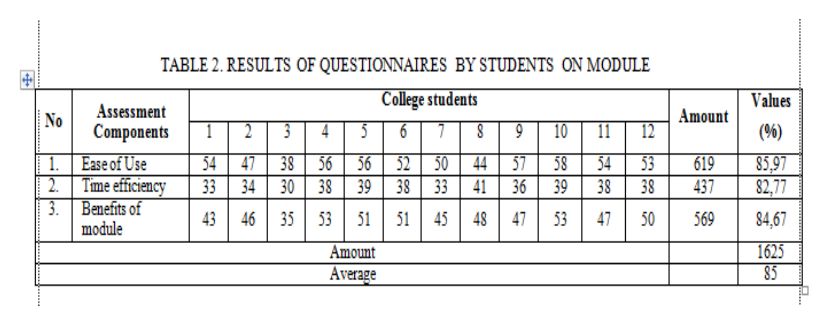

Based on Table 2, it can be seen that the result of questionnaires by students on IRE module is a practical criterion. In the aspect of ease of use module $85.97 \%$, this is caused the IRE module can be used repeatedly and can be used if there is no lecturer. This can happen because the instructions for using the IRE module are easy to understand. The characteristics of a learning media, that is independent, in the sense of providing convenience and completeness of the contents in such a way that the user can use without the guidance of others (Ginanjar, 2010)

Time efficiency aspect of the module $82.77 \%$ this indicates the IRE module can save the lecturer time in explaining IRE module because it does not require a long time like explaining the material without using the IRE module. The benefit aspect of the module is $84.67 \%$ which means IRE module is useful in IRE learning process in STKIP PGRI Sumatera Barat. IRE module can be building foster student's character and mentality.

IRE module nuanced anti radicalism and terrorism is categorized practically with a practical value of $85 \%$. Module development has also been done by Megahati and Yanti, 2018 "Development of student workbook based on Mastery learning in Genetics course" with practice value of $81,27 \%$. Developing an entrepreneurship module 81.63 with a very practical category (Yulastri et al., 2017). Practicality is the level of learning device utilization, by conducting trials using modules that have been declared valid by the validator.

Through the results of interviews can be obtained information that the presentation of materials and activities can help students in building a conceptual understanding. Instructions and commands in activities and exercises are clear, easy to understand, and have been using good and correct Indonesian. IRE module nuanced anti-radicalism and terrorism can form the character of students to live tolerant in religious diversity and cultured according to the philosophy of Bhineka Tunggal Ika. According to Fatkhuri, 2017 "Factors supporting radicalism and terrorism grow because of two fundamental factors, namely economic deprivation and political injustice". IRE module nuanced anti-radicalism and terrorism, causing students are not easily affected by acts of terrorism and radicalism. The IRE module at the university contains material derived from the Qur'an and hadith which describes the humanistic and tolerant teachings of Islam.

The humanistic teachings of Islam are built on the basis of humanity which involves the relations of 
fellow Muslims with other human beings. Humanism in Islam is based on several elements, namely love, compassion and always keep together (Muqoyyidin, 2013). The teachings of Islam strongly uphold the spirit of tolerance which means to up hold the diversity. Includes diversity of religious expression, diversity of streams and beliefs (Rokhmad, 2012). The PAI module contributes to positive thinking especially for students to avoid the insights that have been contaminated by the interests of a small part of Muslims who mistakenly understand the true teachings of Islam.

\section{ACKNOWLEDGMENT}

The authors would like to thank DRPM DIKTI for helping in funding this research. Thanks to all parties who have helped in the research and writing of this manuscript. Thank you to Dr. Ruth Rize Paas Megahati who has helped in writing the manuscript and her suggestions.

\section{REFERENCES}

[1] W. Dick, Carey, L., and Carey, J.O."The Systematic Design of Instruction," Fifth Education New York: Longman, 2000.

[2] Fatkhur. "Faktor Pendukung Terbentuknya Radikalisme dan Terorisme di Indonesia. www.researchgate

[3] A. Ginanjar, "Pengembangan media pembelajaran modul interaktif mata kuliah pemindahan tanah mekanik," in Thesis Fakultas Ilmu Keguruan Universitas Sebelas Maret. Surakarta, 2010.
[4] W. Laqueur, "Terrorism," Boston, MA: Little, Brown. 1977

[5] N. Kosim, "Pengembangan dan Aplikasi Pembelajaran PAI di SD", Jurnal Qathruna. 2( 2), 2015.

[6] A. Prastowo, "Panduan Kreatif Membuat Bahan Ajar yang Inovatif. Yogyakarta: Diva Press.

[7] R. Rufii1, "Developing Module on Constructivist Learning Strategies to Promote Students' Independence and Performance". International Journal of Education. 7(118), 2015.

[8] Megahati, R. R. P and F. Yanti, "Practicality Students Worksheet Based on Mastery Learning in Sex-Linked Gene Material". International Journal of Advanced.and Research. 6(1):164$167,2018$.

[9] Muqoyyidin, A.W, "Membangun Kesadaran Inklusif-multikultural untuk Deradikalisasi Pendidikan Islam,”. Jurnal Pendidikan Islam. 3(1), 2013.

[10] Rokhmad, A, "Pemahaman antiradikalisme dan terorisme di sekolah," Jurnal WaliSongo. 20 (1), 2012.

[11] Sugiyono, "Metodologi Penelitian Pendidikan: Pendekatan Kuantitatif, Kualitatif, dan $R \& D$ ”. Bandung: Alfabeta, 2008.

[12] Trianto, "Model Pembelajaran Terpadu: Konsep, Strategi, dan Implementasi dalam Kurikulum Tingkat Satuan Pendidikan (KTSP)," Jakarta: Bumi Aksara, 2010.

[13] Riduwan, "Belajar Mudah Penelitian untuk Guru, Karyawan, dan Peneliti Pemula,". Bandung: Alfabeta, 2010.

[14] Yulastri, A, Hidayat et al., "Developing an Entrepreneurship Module by Using ProductBased Learning Approach in Vocational," International Journal of Environmental \& Science Education. 12(5): 1097-1109, 2017. 